\title{
The Decomposition of Leaf Litters of Some Tree Species in Temperate Deciduous Forest in Korea II. Changes in Nutrient Content During Litter Decomposition
}

\author{
Yang, Keum-Chul ${ }^{*}$ and Jae-Kuk Shim ${ }^{1}$ \\ Dept. of Environmental Engineering, Cheonan National Technical College, Cheonan, Chungnam 330-717, Korea \\ ${ }^{\prime}$ Dept. of Life Science, Chung-Ang University, Seoul 156-756, Korea
}

\begin{abstract}
Dry weight loss and nutrient release from leaf litter for six tree species were studied using litter bag methods. The litter bags were incubated for 16 months on the forest floor in temperate deciduous forest in Mt. Cheonma, located at the middle part of Korean Peninsula. The changes in nutrient content and the rate of dry weight loss in leaf litter varied with litter types. The litter of Pinus densiflora showed the lowest rate of mass loss $(k=0.33)$, nitrogen concentration $(0.89 \%)$ and ash concentration $(2.50 \%)$, while showed the highest $\mathrm{C} / \mathrm{N}$ ratio (63.40). On the other hand, the litter of Acer pseudo-sieboldianum showed the fastest rate of mass loss $(k=0.82)$, the highest nitrogen concentration (1.11\%), and the lowest $\mathrm{C} / \mathrm{N}$ ratio (49.40). During the decomposition, nitrogen, phosphorus and calcium in the leaf litters showed relatively slow decreasing pattern compared to other elements (carbon, potassium, magnesium, manganese and sodium), but potassium and sodium decreased at early stage of the decomposition for all leaf litters.

Differences in annual decomposition rates of litter among species were consistent with the particular chemical characteristics of their leaf litters. The initial concentration of nitrogen was positively correlated with litter decomposition rate for six species, while litter decomposition rate of six species was negatively correlated with $\mathrm{C}: \mathrm{N}$ ratio of initial leaf litters.
\end{abstract}

Key words : C:N ratio, Decomposition rate, Litter decomposition, Nutrient elements

\section{INTRODUCTION}

Litter decomposition is the fundamental process of terrestrial ecosystem because it is a major determinant of nutrient cycling and regulator of nutrient availability needed for plant growth. The decomposition consists of three basic processes; biological action, weathering and leaching (Swift et al. 1979, Moretto et al. 2001, Koukoura et al. 2003). Therefore, soil biota, litter quality and physicochemical environment are very important factors affecting the decomposition rate.

Plant nutrients are released from litter either by physical leaching or breakdown of structural organic components by soil organisms. The rates at which elements are released from litter are generally governed by the rate of dry weight loss during decomposition. However, each nutrient releases at different rate and exhibits different release patterns because the chemical composition and litter quality are dependent on the litter types.
Inorganic non-structural elements such as sodium, potassium, magnesium and manganese are susceptible to initial leaching (Gosz et al. 1973, Bockheim et al. 1991, Laskowski et al. 1995, Semwal et al. 2003). In addition, the release of organic structural elements are affected by litter quality such as chemical composition, palatability and hardness (Melillo et al. 1982, Taylor et al. 1989, Cotrufo et al. 1995, Moretto et al. 2001, Smith and Bradford 2003).

After a study about the decomposition rate of some litter in Korea by Kim and Chang (1965), Kwak and Kim (1992) and Mun and Pyo (1994) surveyed the release of plant nutrients during decomposition of the litter.

In this study, we studied the mass loss and release of major nutrient elements from the decomposing leaf litter of tree species dominated in temperate forest in the middle part of Korean Peninsula, and examined the releasing pattern of each nutrient for 16 months of experimental period. Also, we investigated the relationship between dry weight loss of litter and litter quality such as chemical composition and $\mathrm{C} / \mathrm{N}$ ratio in the fresh leaf litter.

\footnotetext{
* Corresponding author; Phone: 82-41-550-0384, Fax: 82-41-569-6569, e-mail: yangkc@cntc.ac.kr
} 


\section{MATERIALS AND METHODS}

\section{Study site}

This study was conducted for 16 months (Nov. 1993 Mar. 1995) in a natural secondary oak forest dominated by Quercus mongolica (DBH 5 20cm) in Mt. Cheonma $\left(127^{\circ} 17^{\prime} \mathrm{E}, 37^{\circ} 40^{\prime} \mathrm{N}\right)$. The understory vegetation was dominated by Disporum smilacinum, Carex siderostica, Smilax nipponica, etc. and showed $80 \%$ coverage. The soil is a sandy loam with $\mathrm{pH} 5.9$ and brown forest soil with well developed soil horizons. More details on the experiment site were provided by Yang and Shim (2003).

\section{Litter bag experiment}

Fresh leaf litter of the six dominant species (Quercus mongolica, Q. serrata, Carpinus laxiflora, Pinus densiflora, Acer pseudosieboldianum and Betula ermani) was collected in Oct. 1993 from the study area. In nylon litter bag $(18 \mathrm{~cm} \times 18 \mathrm{~cm})$ with $1.3 \mathrm{~mm}$ $\times 1.3 \mathrm{~mm}$ mesh size, about $2 \mathrm{~g}$ of leaf litter was placed. Total 720 litter bags were placed in an area of $100 \mathrm{~m}^{2}$ and arranged in a randomized complete block design. All litter bags were numbered and naturally placed on the litter layer. The litter bags were retrieved with ten replications for each litter at an interval of about 3 months.

\section{Analysis of litter samples}

The retrieved and dried litter samples were weighed and ground with Willy mill to pass through $1 \mathrm{~mm}$ sieve for chemical analysis. The ash after sample ignition at $500^{\circ} \mathrm{C}$ for $4 \mathrm{hr}$ dissolved in $\mathrm{HCl}$ (1:1), and then diluted with $\mathrm{H}_{2} \mathrm{O}$ and filtered through Whatman No. 1. This filtrate was used for determination of phosphorus (P), potassium $(\mathrm{K})$, calcium $(\mathrm{Ca})$, magnesium $(\mathrm{Mg})$, manganese $(\mathrm{Mn})$ and sodium (Na) using Inductively Coupled Plasma (ICP) Atomic Emission Spectrometer (Jobin Yvon JY-24) by a method by Helrich (1990).

Total carbon (C) was analyzed using $25 \mathrm{~mL} 0.0675 \mathrm{M}$ chromic acid mixture and $0.4 \mathrm{M}\left(\mathrm{NH}_{4}\right)_{2} \mathrm{SO}_{4} \cdot \mathrm{FeSO}_{4} \cdot 6 \mathrm{H}_{2} \mathrm{O}$ solution by rapid titration method (Allen et al. 1974). Total nitrogen (N) was analyzed by semi-micro Kjeldahl procedure after digestion in $2 \mathrm{~g} \mathrm{~K}_{2} \mathrm{SO}_{4}+\mathrm{HgO}$ catalyst and $3 \mathrm{~mL}$ concentrated $\mathrm{H}_{2} \mathrm{SO}_{4}$. The concentrations of all elements except $\mathrm{C}$ and $\mathrm{N}$ are the results of three replicates.

\section{Calculation}

By combining these results with data on dry weight loss, the remaining amounts of each element after different incubation periods were calculated. Percentage of the nutrient remaining in decomposing leaf litter was derived from the equation below.
$\%$ Nutrient remaining $=\left(C / C_{0}\right) \times\left(\mathrm{DM} / \mathrm{DM}_{0}\right) \times 100$

Where $C$ is the concentration of element in the leaf litter at the time of sampling; $C_{\theta}$ is the concentration of the initial litter used for decomposition; DM is the mass of dry matter at time of sampling; and $\mathrm{DM}_{0}$ is the mass of initial dry matter of the litter sample used for decomposition (Bockheim et al. 1991).

The decomposition constant $(\mathrm{k})$ of nutrient release was calculated by Olson's $\mathrm{X}=\mathrm{X}_{0} \mathrm{e}^{-\mathrm{kt}}$, where $\mathrm{X}_{0}$ is the initial amount of litter, $\mathrm{X}$ is the amount of litter remaining after time $t$, and $t$ is the time (in years), respectively (Olson 1963). All statistical analyses were conducted using statistical analysis package of MINITAB (MINITAB 2002).

\section{RESULTS AND DISCUSSION}

\section{Dry weight loss}

The remaining of dry weight of each litter in litter bag was decreased with time. The slopes $\mathrm{k}$ of all parameters of the regression $\mathrm{X}=\mathrm{X}_{0} \mathrm{e}^{-\mathrm{kt}}$ are given in Table 1 .

To investigate the pattern of dry weight loss with time, percentage of dry weight remaining was regressed against the time (days) as exponential equation. The regression equations for six species litters are given in Table 1 . In all cases, the determination coefficient $\left(r^{2}\right)$ was significant at $\mathrm{P}<0.001$.

\section{Nutrient element dynamics in the decomposing leaf litter}

The percentage of $\mathrm{C}$ remaining in decomposing leaf litters for six species were decreased with time. The extent of $C$ loss varied with species; $Q$. mongolica, $Q$. serrata and $P$. densiflora with relatively small decrease in $\mathrm{C}$ content compared to those of other three species (Fig. 1(B)). Also, the pattern of C loss was similar to that of dry weight loss (Fig. 1(A)).

Nitrogen release after four months was fastest in $A$. pseudo

Table 1. Relationship between percentage dry weight remaining of six species litters ( $\mathrm{y}$ ) and number of days elapsed $(\mathrm{x})$

\begin{tabular}{lccc}
\hline \multicolumn{1}{c}{ Species } & $\begin{array}{c}\text { Decomposition } \\
\text { constant }\left(k^{*}\right)\end{array}$ & Regression equation & $r^{2}$ \\
\hline Q. mongolica & 0.43 & $\mathrm{y}=100.30 \times \mathrm{e}^{-0.0013 \mathrm{x}}$ & 0.94 \\
Q. serrata & 0.37 & $\mathrm{y}=100.50 \times \mathrm{e}^{-0.0012 \mathrm{x}}$ & 0.93 \\
C. laxiflora & 0.75 & $\mathrm{y}=99.11 \times \mathrm{e}^{-0.0022 \mathrm{x}}$ & 0.97 \\
P. densiflora & 0.33 & $\mathrm{y}=100.26 \times \mathrm{e}^{-0.0010 \mathrm{x}}$ & 0.95 \\
A. pseudo-sieboldianum & 0.82 & $\mathrm{y}=94.12 \times \mathrm{e}^{-0.0024 \mathrm{x}}$ & 0.94 \\
B. ermani & 0.66 & $\mathrm{y}=96.64 \times \mathrm{e}^{-0.0020 \mathrm{x}}$ & 0.94 \\
\hline
\end{tabular}

* Data from Yang and Shim (2003). 

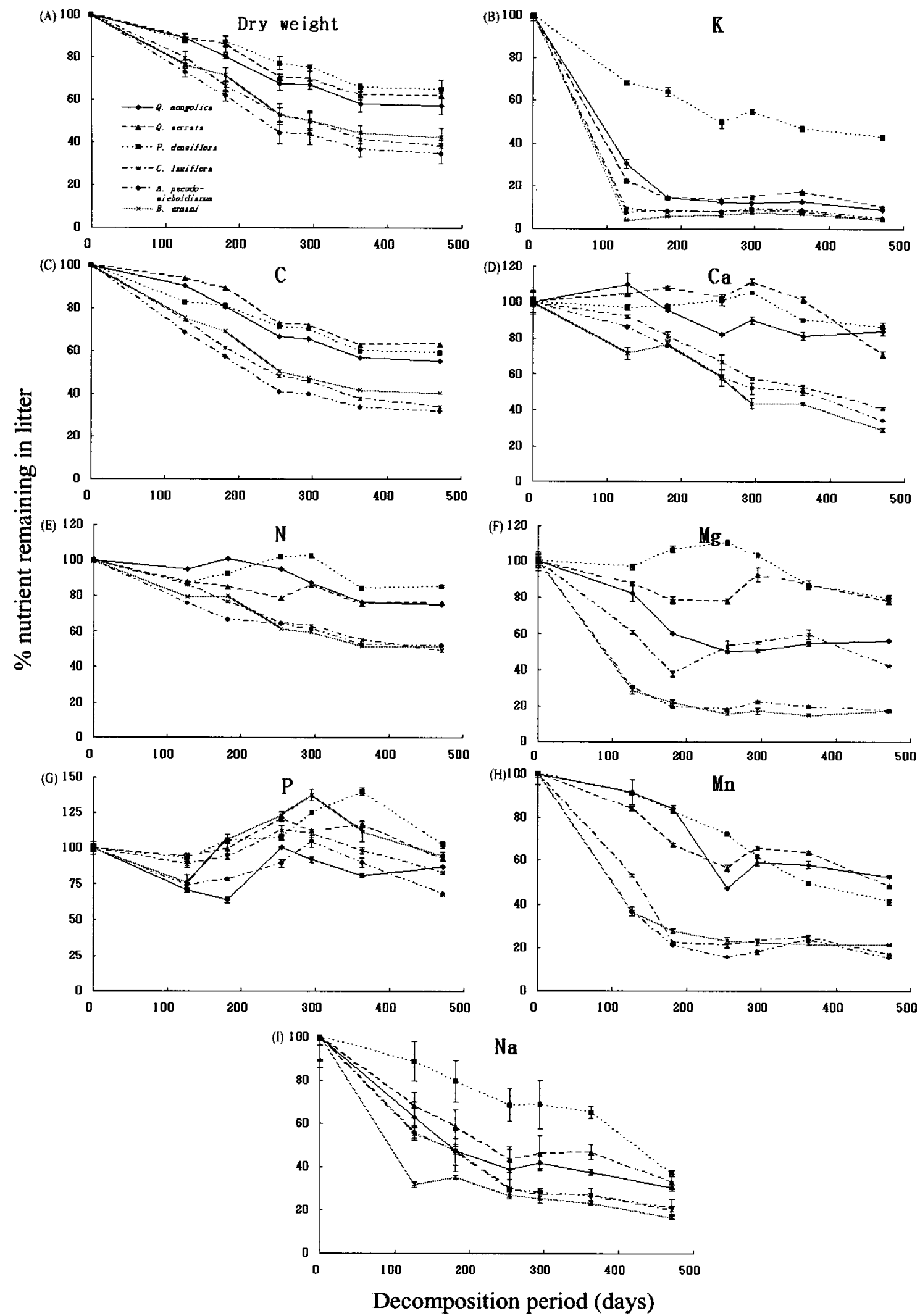

Fig. 1. Dry weight and nutrients remaining (\%) in the litter bags for six tree species with various collection time intervals in Mt. Cheonma, south Korea. The vertical lines represent a standard deviation. (A)is data from Yang and Shim (2003). 
sieboldianum (24\%), whereas Q. mongolica showed only $5.5 \%$ release rate (Fig. $1(\mathrm{C})$ ). The release of $\mathrm{N}$ was relatively lower than dry weight loss in all species (Fig. 1(A)). Increases of $\mathrm{N}$ content in pine litter might be due to the input from the environment. Similar accumulations of $\mathrm{N}$ have been observed in many litter bag experiments and were probably the results of one or more processes including absorption of $\mathrm{N}$ from atmospheric precipitation or imports of $\mathrm{N}$ in fungal hyphae and contaminating debris (Bocock 1963, Gosz et al. 1973, Lousier and Parkinson 1978, Berg and Staaf 1981).

The release rate of $P$ was slower than the dry weight loss of the litter from all species (Fig. 1(A)). Also, there was an accumulation of $\mathrm{P}$ in the litter for all species (Fig. 1(D)), which might result from the microfauna on the litter (Will 1967). Potassium showed the fastest release rate, particularly much of it was released in the early stage of decomposition (Fig. 1(E)). Several studies reported that since the initial content of $\mathrm{K}$ in the litter was beyond the decomposer demand and $\mathrm{K}$ was not structural component of plant tissue, it could be released easily (Gosz et al. 1973, Brown 1974).

Attiwill (1967) and Upadhyay and Singh (1989) indicated that Ca was much less susceptible to leaching and was a more important structural component of leaf tissue than $\mathrm{K}$ and $\mathrm{Na}$. The pattern of Ca loss from the litter of C. laxiflora, A. pseudo-sibodianum and $B$. ermani was closely paralleled with that of weight loss throughout decomposition (Fig. 1(F), Fig. 1(A)). Calcium release rate in $Q$. mongolica, $Q$. serrata and $P$. densiflora was slower than dry weight loss. Also, Ca of these species seemed to be temporarily immobilized during decomposition. Many workers reported that the $\mathrm{Ca}$ may be transferred from the forest floor to the decomposing litter through attached fungal hyphae (Fahey 1983, Waring and Schlesinger 1985).

The dynamic patterns of $\mathrm{Mg}$ content differed among species (Fig. $1(G)$ ). The differences may be a consequence of the difference in the initial $\mathrm{Mg}$ concentration of the leaf litter. A. pseudo-sieboldianum and $B$. ermani had relatively high initial $\mathrm{Mg}$ concentrations (\%), which were 0.248 and 0.324 , respectively, compared with $Q$. serrata $(0.087)$ and $P$. densiflora $(0.050)$ (Table 3$)$. So, $\mathrm{Mg}$ in litter for $A$. pseudo-sieboldianum and $B$. ermani was more rapidly released than that of other species. This suggests that a certain quantity of $\mathrm{Mg}$ was required by decomposer and that in excess was easily released (Gosz et al. 1973).

In $Q$. serrata, $P$. densiflora and $Q$. mongolica, the release rates of Mn were similar to those of dry weight loss and in C. laxiflora, A. pseudo-sieboldianum and B. ermani the release rates of $\mathrm{Mn}$ were much faster than those of dry weight loss (Fig. 1(H), Fig. 1(A)).

The release rate of $\mathrm{Na}$ was faster than dry weight loss for all species (Fig. 1(I), Fig. 1(A)). Evidently Na were actively leached so that the litter residue had a lower content than the original litter as shown by $\mathrm{K}$ in this study. Almost half of $\mathrm{Na}$ was leached from decomposing litter for $Q$. mongolica and $Q$. serrata within 6 months, and a third of the initial content remained after 1.5 years. In $B$. ermani, almost $68 \%$ of initial content of $\mathrm{Na}$ was released from decomposing litter within first 4 months.

In terms of the releasing rate calculated, the releasing rate of $\mathrm{K}$ showed the highest in all species except for $P$. densiflora (Table 2). A. pseudo-sieboldianum showed the highest rate of release for $\mathrm{C}, \mathrm{P}$,

Table 2. Nutrient releasing rate of six tree species leaf litter in Mt. Cheonma, south Korea. The calculation of the releasing rate was based on Olson's equation $\mathrm{X}=\mathrm{X}_{0} \mathrm{e}^{-\mathrm{kt}}$

\begin{tabular}{|c|c|c|c|c|c|c|}
\hline Nutrients $\quad$ Species & Q. mongolica & Q. serrata & C. laxiflora & P. densiflora & A. pseudo-sieboldianum & B. ermani \\
\hline Carbon & 0.46 & 0.36 & 0.83 & 0.41 & 0.89 & 0.70 \\
\hline Nitrogen & 0.23 & 0.21 & 0.55 & 0.13 & 0.51 & 0.52 \\
\hline Phosphorus & 0.11 & 0.06 & 0.14 & ND & 0.30 & 0.04 \\
\hline Potassium & 1.86 & 1.78 & 2.42 & 0.66 & 2.29 & 2.34 \\
\hline Calcium & 0.14 & 0.27 & 0.69 & 0.12 & 0.83 & 0.96 \\
\hline Magnesium & 0.45 & 0.19 & 0.67 & 0.17 & 1.37 & 1.36 \\
\hline Manganese & 0.50 & 0.56 & 1.37 & 0.69 & 1.44 & 1.19 \\
\hline Sodium & 0.92 & 0.86 & 1.24 & 0.77 & 1.20 & 1.38 \\
\hline
\end{tabular}

ND; not-determined. 
$\mathrm{Mg}$ and $\mathrm{Mn}$. The highest rate of release for $\mathrm{N}$ and $\mathrm{K}$ was observed in $C$. laxiflora and the lowest in $P$. densiflora. The highest rate of release for $\mathrm{Ca}$ and $\mathrm{Na}$ was observed in $B$. ermani and the lowest in $P$. densiflora. The latter also showed the lowest rate of release for $\mathrm{Mg}$.

Initial chemical composition of leaf litter and dry weight loss

Chemical composition of leaf litter in the present study was highly variable (Table 3 ). $\mathrm{N}$ concentration of initial litter was highest for $A$. pseudo-sieboldianum (1.11\%) and lowest for $P$. densiflora $(0.89 \%)$. P. densiflora had the lowest concentration of $\mathrm{Ca}, \mathrm{K}, \mathrm{Na}, \mathrm{Mn}$ and $\mathrm{Mg}$. This resulted in the lowest content of ash in $P$. densiflora. Waring and Schlesinger(1985), Taylor et al.(1989), Moretto et al.(2001) and Koukoura et al.(2003) reported the differences in concentration of each element within litter species. Melillo et al.(1982), Taylor et al.(1989), Cotrufo et al.(1995) and Smith and Bradford (2003) suggested that litter decomposition rate was dependent not only on these chemical composition of litter but also on climate and soil biodiversity.

Each leaf litter samples showed similar $\mathrm{C}$ concentration but exhibited various $\mathrm{N}$ concentration among the species. Therefore, $\mathrm{C}: \mathrm{N}$ ratio of the leaf litter in this study was determined by $\mathrm{N}$ concentration. Pine showed the lowest $\mathrm{N}$ concentration (0.89), oak species about $0.9 \%$, and maple and birch above $1 \%$. The highest C:N ratio was 63.4 in $P$. densiflora and the lowest $\mathrm{C}: \mathrm{N}$ ratio was 49.4 in $A$. pseudo-sieboldianum. This difference in C:N ratio might account for the lowest decomposition rate of $P$. densiflora and the highest of $A$. pseudo-sieboldianum.

The correlation between dry weight loss of each leaf litter and their initial $\mathrm{N}$ concentration showed a positive relationship, while dry weight loss of each leaf litter showed negative relationship with $\mathrm{C}: \mathrm{N}$ ratio (Fig. 2). The $\mathrm{C}: \mathrm{N}$ ratio of the leaf litter of quickly decomposing species (A. pseudo-sieboldianum and $C$. laxiflora) were lower than those of other species with slow decomposition rate ( $P$. densiflora and $Q$. serrata).

Many previous workers also found such positive relationship (Taylor et al. 1989, Constantinides and Fownes 1994, Cotrufo et al. 1995, Jamaludheen and Kumar 1999, Smith and Bradford 2003). Cotrufo et al. (1995) and Smith and Bradford (2003) defined that good quality of litter showed high content of $\mathrm{N}$ and low value of C:N ratio. This litter quality provides palatable or unpalatable sources to the soil organism (Moretto et al. 2001), controls decomposition of hardwood leaf litter (Melillo et al. 1982) and could be used as predictors of litter decay rates (Taylor et al. 1989). Salamanca et al.(2003) reported leaf litters of $Q$ serrata and $Q$. accutissima with lower $\mathrm{C}: \mathrm{N}$ ratio were decomposed faster than $P$. densiflora with higher $\mathrm{C}: \mathrm{N}$ ratio.

In conclusion, Pinus densiflora showed the lowest rate of mass loss, nitrogen concentration and ash concentration, while showed the highest $\mathrm{C} / \mathrm{N}$ ratio. However, Acer pseudo-sieboldianum showed the fastest rate of mass loss, the highest nitrogen concentration, and the lowest $\mathrm{C} / \mathrm{N}$ ratio. Nitrogen, $\mathrm{P}$ and $\mathrm{Ca}$ in the leaf litters showed relatively slow decreasing pattern compared to other elements, but $\mathrm{K}$ and $\mathrm{Na}$ decreased at early stage of the decomposition for all leaf

Table 3. Initial concentrations of chemical elements in leaf litters of six species in Mt. Cheonma

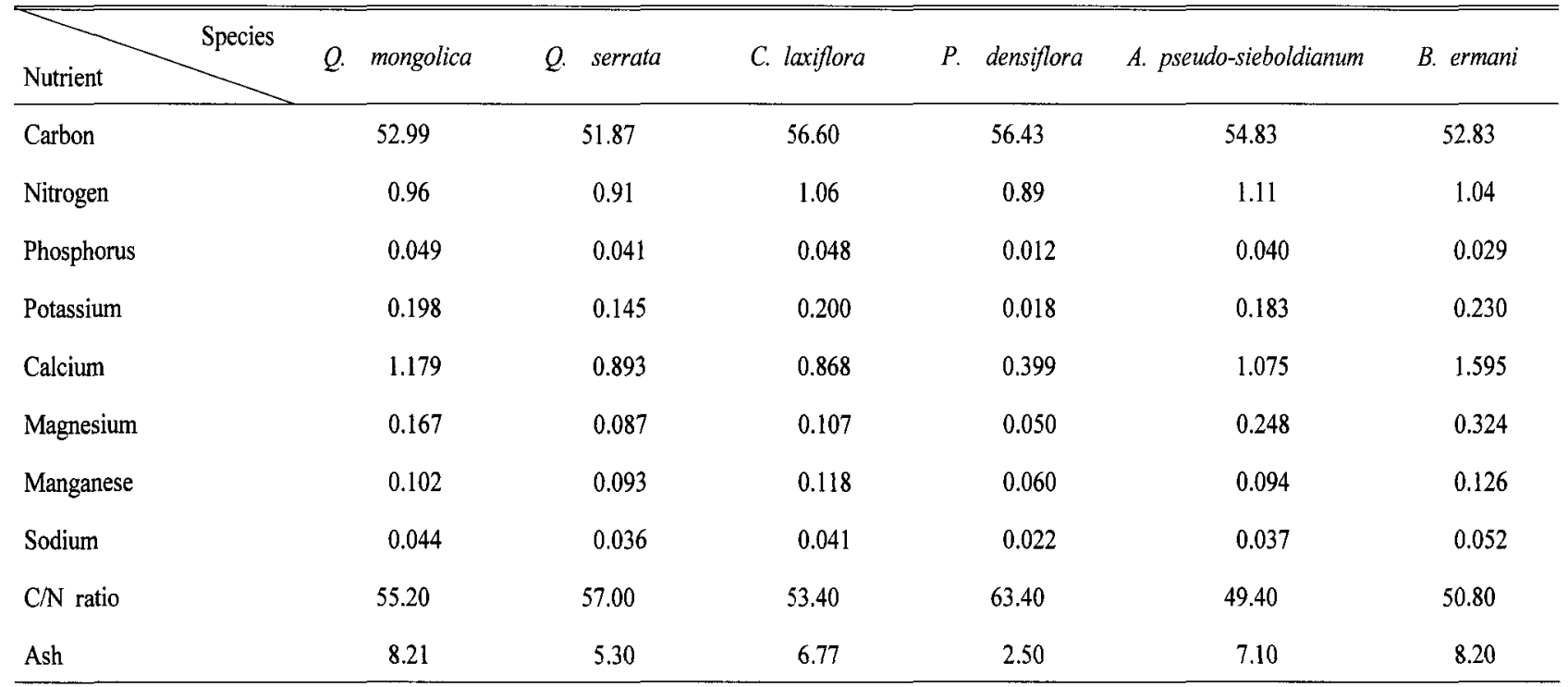

Values in $\%$ of dry weight. 

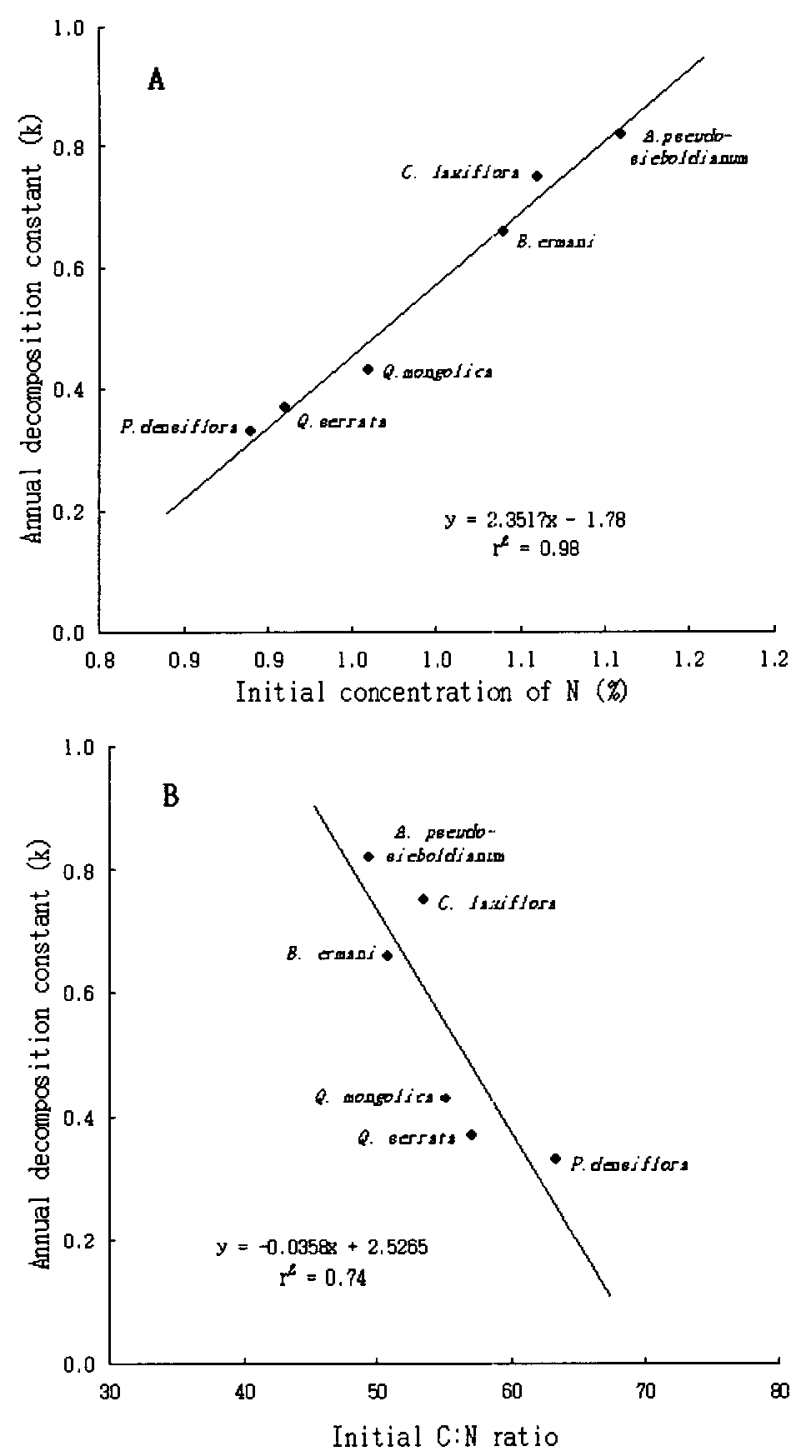

Fig. 2. Results of linear regressions of annual decomposition constants (k) of six species leaf litters against initial nitrogen concentration (A) and $\mathrm{C}: \mathrm{N}$ ratio (B).

litters.

Annual rates of litter decomposition among species showed close associations with the particular chemical characteristics of their leaf litters. Also, the initial concentration of nitrogen exhibited a positive relationship with litter decomposition rate for all species, while litter decomposition rate of six species was negatively correlated with $\mathrm{C}: \mathrm{N}$ ratio of initial leaf litters.

\section{LITERATURE CITED}

Allen, S.E., H.M. Grimshaw, J.A. Parkinson and C. Quarmby. 1974.
Chemical analysis of ecological materials. Blackwell. Oxford. England. 565p.

Attiwill, P.M. 1967. The loss of elements from decomposing litter. Ecology 49: 142-145.

Berg, B. and H. Staaf. 1981. Leaching, accumulation and release of nitrogen from decomposing forest litter. In: Terrestrial nitrogen cycles. processes, ecosystem strategies and management impacts. Ecol. Bull. 33: 163-178.

Bockheim, J.G., E.A. Jepsen and D.M. Heisey. 1991. Nutrient dynamics in decomposing leaf litter of four tree species on a sandy soil in north-western Wisconsin. Can. J. For. Res. 21: 803-812.

Bocock, K.L. 1963. Changes in the amount of nitrogen in decomposing leaf litter of sessile oak (Quercus petraea). J. Ecol. 51: 555-566.

Brown, A.H.F. 1974. Nutrient cycles in oakwood ecosystems in N.W. England. The British Oak, pp.141-161.

Constantinides, M. and J.H. Fownes. 1994. Nitrogen mineralization from leaves and litter of tropical plants: relationship to N, lignin and soluble polyphenol concentrations. Soil Biol. Biochem. 26(1): 49-55.

Cotrufo, M.F., P. Ineson and D. Roberts. 1995. Decomposition of birch leaf litters with varying C-to-N ratio. Soil Biol. Biochem 27: 1219-1221.

Fahey, T.J. 1983. Nutrient dynamics of aboveground detritus in lodgepole pine (Pinus contorta subsp. latifolia) ecosystems in southeastern Wyoming. Ecol. Monogr. 53: 51-72.

Gosz, J.R., G.E. Likens and F.H. Bormann. 1973. Nutrient release from decomposing leaf and branch litter in the Hubbard Brook forest, New Hampshire. Ecol. Monogr. 43: 173-191.

Helrich, K. 1990. Official methods of analysis of the association of official analytical chemists. AOAC, Inc. USA. 1298p.

Jamaludheen, V. and B.M. Kumar. 1999. Litter of multipurpose trees in Kerala, India: variations in the amount, quality, decay rates and release of nutrients. For. Ecol. Manage. 115: 1-11.

Kim, C.M. and N.K. Chang. 1965. The decomposition rate of litter affecting the amount of mineral nutrients of forest soil in Korea. Bull. Ecology Soc. Am., Sep. 14p.

Koukoura, Z., A.P. Mamolos and K.L. Kalburtji. 2003. Decomposition of dominant plant species litter in a semi-arid grassland. Appl. Soil Ecol. 23: 13-23.

Kwak, Y.S. and J.H. Kim. 1992. Nutrient cyclings in mongolian oak (Quercus mongolica) forest. Korean J. Ecol. 15(1): 35-46.

Laskowski, R, M. Niklinska and M. Maryanski. 1995. The dynamics of chemical elements in forest litter. Ecology 76(5): 1393-1406.

Lousier, J.D. and D. Parkinson. 1978. Chemical element dynamics in decomposing leaf litter. Can. J. Bot. 56: 2795-2812. 
Melillo, J.M., J.D. Aber and J.F. Muratore. 1982. Nitrogen and lignin control of hardwood leaf litter decomposition dynamics. Ecology 63: 621-626.

MINITAB. 2002. MINTAB user's guide. Releas 13, Minitab Inc., Pennsylvania, USA.

Moretto, A.S., R.A. Distel and N.G. Didone. 2001. Decomposition and nutrient dynamic of leaf litter and roots from palatable and unpalatable grasses in a semi-arid grassland. Appl. Soil Ecol. 18: $31-37$.

Mun, H.T. and J.H. Pyo. 1994. Dynamics of nutrient and chemical constituents during litter decomposition. Korean J. Ecol. 17(4): 501-511. (in Korean with English abstract).

Olson, J.S. 1963. Energy storage and the balance of producers and decomposers in ecological systems. Ecology 44: 322-331.

Salamanca, E.F., N. Kaneko and S. Katagiri. 2003. Rainfall manipulation effects on litter decomposition and the microbial biomass of the forest floor. Appl. Soil Ecol. 22: 271-281.

Semwal, R.L., R.K. Maikhuri, K.S. Rao, K.K. Sen and K.G. Saxena. 2003. Leaf litter decomposition and nutrient release patterns of six multipurpose tree species of central Himalaya, India. Biomass and Bioenergy 24: 3-11.

Smith, V.C. and M.A. Bradford. 2003. Litter quality impacts on grassland litter decomposition are differently dependent on soil fauna across time. Appl. Soil Ecol. 24: 197-203.

Swift, M.J., O.W. Heal and J.M. Anderson. 1979. Decomposition in terrestrial ecosystems. University of California Press, Berkeley. $372 \mathrm{p}$.

Taylor, B.R., D. Parkinson and W.F.J. Partons. 1989. Nitrogen and lignin content as predictors of litter decay rates: A microcosm test. Ecology 70: 97-104.

Upadhyay, V.P. and J.S. Singh. 1989. Patterns of nutrient immobilization and release in decomposing forest litter in central Himalaya, India. J. Ecol. 77: 127-146.

Waring, R.H. and W.H. Schlesinger. 1985. Forest ecosystems: concepts and management. Academic Press, New York, pp. 181-210.

Will, G.M. 1967. Decomposition of Pinus radiata litter on the forest floor. Part 1. Changes in dry matter and nutrient content. N. Z. Jl. Sci. 10: 1030-1044.

Yang, K.C. and J.K. Shim. 2003. The decomposition of leaf litters of some tree species in temperate deciduous forest in Korea. I. Losses in dry weight of leaf litter. Korean J. Ecol. 26(4): 203-208.

(Received November 10, 2003; Accepted December 21, 2003) 